\title{
Is there a link between autism and glyphosate-formulated herbicides?
}

\author{
James E. Beecham ${ }^{1}$ and Stephanie Seneff2 ${ }^{*}$
}

*Correspondence: seneff@csail.mit.edu

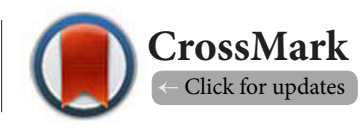

${ }^{1}$ Consultant Pathologist (Retired) University of Florida, Gainesville, USA.

${ }^{2} \mathrm{MIT}$ Computer Science and Artificial Intelligence Laboratory, Massachusetts Institute of Technology, USA.

\begin{abstract}
Glyphosate is the most widely used herbicide on the planet, and its increasing use over time in the United States aligns well with the increasing rates of autism determined by the Centers for Disease Control. Based on the known mechanism of glyphosate toxicity, we hypothesize that a pregnant woman's exposure at midpregnancy to glyphosate-formulated herbicides $(\mathrm{GFH})$ may produce, in her unborn child's brain, anatomic alterations of cortical neuron layering remarkably similar to those found in the brains of humans with autism. Glyphosate's known ability to chelate manganese ions combined with evidence of severely depleted serum manganese in cows exposed to glyphosate makes it likely that glyphosate would induce manganese deficiency in humans, interfering with the function of manganese-dependent enzymes. In particular, this would affect the maternal pituitary's manganese-dependent Protein Phosphatase 1 (PP1) enzyme, resulting in a significant reduction in maternal serum levels of Thyroid-Stimulating Hormone (TSH). A study of mid-pregnancy maternal TSH serum levels in human mothers has found a statistical correlation of reduced TSH to increased risk of autism in offspring. Since insufficient thyroid stimulation by TSH or by iodine deficiency would both induce hypothyroidism, effects of iodine deficiency can be expected to emulate effects of TSH deficiency. Cortical neuron disarrangements have been produced in the brains of offspring of rat dams fed an iodine-deficient diet, and such foci of disordered cortical neurons are characteristically found in human autistic brains. While the research literature on glyphosate's endocrine disrupting effects is limited, diverse evidence from animal studies reveals effects that suggest impaired thyroid function. If our hypothesis can be substantiated by a focused research effort, it would provide further justification for reducing or, ideally, eliminating glyphosate-formulated herbicide exposures in pregnant women.
\end{abstract}

Keywords: Autism, glyphosate, manganese, hypothyroidism, topoisomerase, protein phosphatase, herbicide, neurodevelopment

\section{Introduction}

The prevalence of autism has been rising at an alarming rate in the United States over the past two decades, as determined for example by the progressive rise in the number of children in the public school system designated as autistic under the Individuals with Disabilities Education act (IDEA). The pattern of this rise is extremely well matched temporally to the rising use of glyphosate on corn and soy crops, as pointed out in an article by Swanson et al., and illustrated in their figure 23, reproduced here as Figure 1 [1]. The data plotted in this figure are readily available from U.S. government sources on the Web, and the correlation is nearly perfect $(0.99)(p<1.1 \mathrm{E}-6)$. While correlation does not necessarily mean causation, it is striking that the only pesticide whose usage rates have gone up dramatically exactly in step with the rise in autism is glyphosate, and it is the most used herbicide on the planet. Pesticides are clearly toxic as that is their intent, and a strong correlation in the rise of a serious disorder with a toxic chemical can not be simply dismissed.

An initiative undertaken by the organization, Moms Across America, has found levels of glyphosate in breast milk ranging from $76 \mathrm{mg} / \mathrm{l}$ to $166 \mathrm{mg} / \mathrm{l}$ in 3 out of 10 test samples (see: http:// www.momsacrossamerica.com/ glyphosate testing results). A European study of glyphosate residues in urine of humans and animals found significantly more glyphosate in the urine of humans eating a conventional diet compared to those eat-

(C) 2016 Seneff et al; licensee Herbert Publications Ltd. This is an Open Access article distributed under the terms of Creative Commons Attribution License (http://creativecommons.org/licenses/by/3.0). This permits unrestricted use, distribution, and reproduction in any medium, provided the original work is properly cited. 
Beecham et al. Journal of Autism 2016,

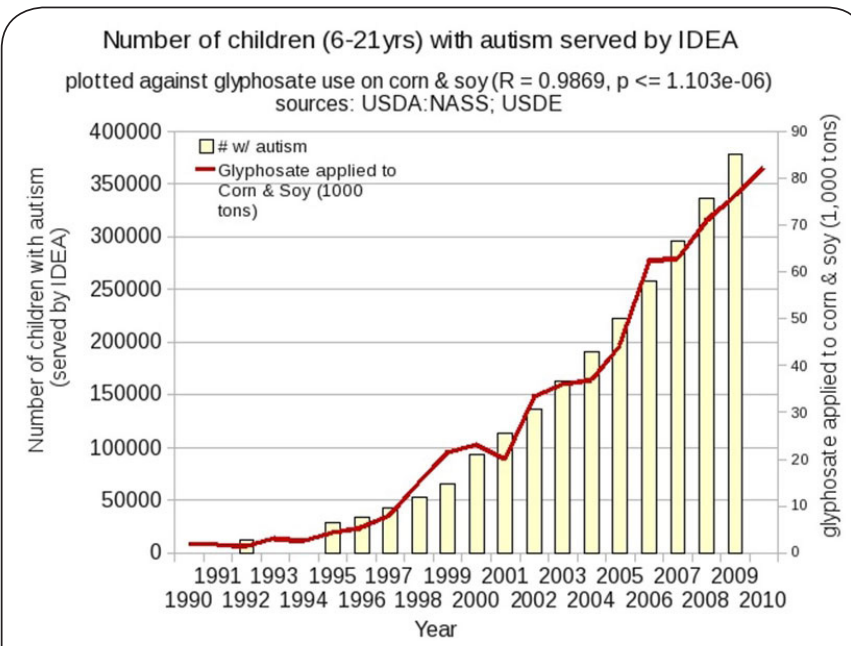

Figure 1. Trends over time in the number of children with autism according to the IDEA and in the use of glyphosate on corn and soy crops. These data are readily available from the U.S. government from Web-based resources. Figure reproduced with permission from Swanson et al. [73].

ing an organic diet $(\mathrm{P}<0.0001)$ [2]. Furthermore, humans with chronic diseases had higher levels than those who were healthy.

In this paper, we develop the hypothesis that glyphosate's potential link to autism can be explained in part through an adverse effect on the thyroid gland of both the mother and the child during gestation. In the developing human brain, in order to form proper neuronal circuits and cortical architecture, neurons must migrate and assemble in an organized manner. Under normal circumstances, immature neurons migrate through the paraventricular white matter to assemble in the neocortex and progressively form, within the gray matter, a distinct 6 layered pattern of neurons [3] (see Figure 2).
Autistic brains, during fetal development, appear to experience a disorder of neuron migration, at least in small foci. Stoner et al., found that autistic brains have small scattered foci of abnormal neocortex in which the usual 6 layers of neurons are instead blurred and ill-defined [4]. In addition to disorder in arrangement, some neurons in autism remained scattered within the white matter, apparently unable to migrate properly through the white matter and into the gray matter (Figure 3) as would normally occur. Neurons within these disordered foci in autistic brains also have a reduced content of calciumbuffering molecules, as demonstrated by reduced CALB1 in-situ hybridization staining. Lopez-Hurtado et al., found autistic brains to have a focal reduction in number of neurons and a focal increase in number of glial cells in areas related to speech processing [5].

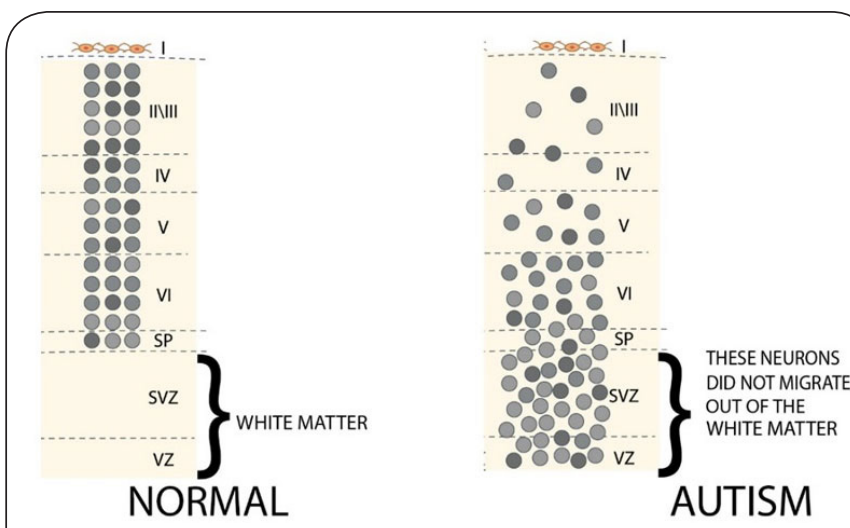

Figure 3. Schematic of neocortex neuron arrangement, normal (left) versus focus of abnormal cortex in autistic brain (right).

Note the autistic brain has small foci with excess neurons, a blurring of layering, and numerous neurons still remaining within the white matter.

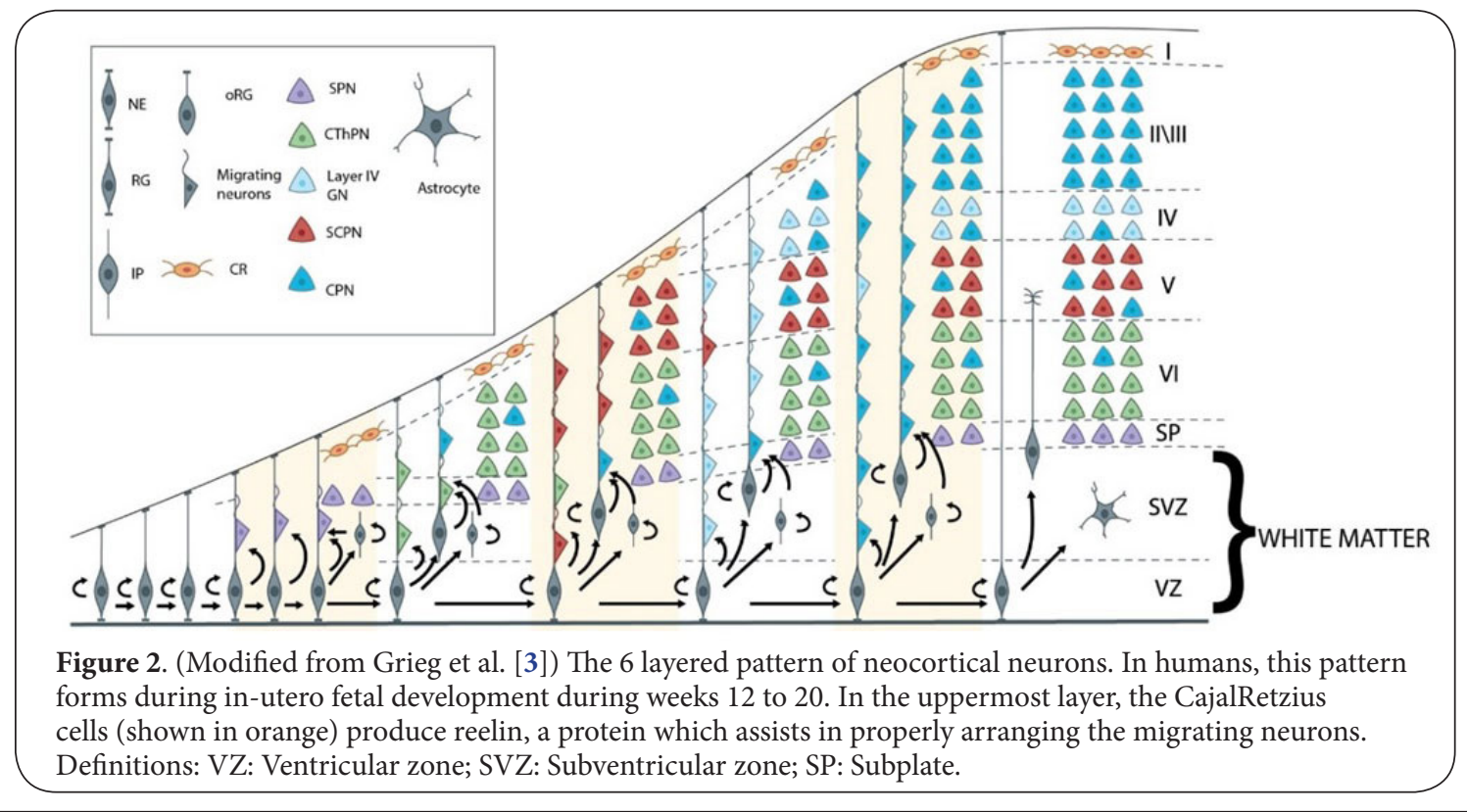


During neurodevelopment in children with autism, there is an excess of focal neurons in the early stages as compared to the same age in typical fetal/childhood development, up to $70 \%$ more neurons in foci early on in autistic brains as compared to normal neurodevelopment. In the neocortex, these extra neurons migrate improperly, forming blurred indistinct layering, with many neurons remaining within the white matter. Stoner et al., found such a pattern in 10 of the 11 autistics they studied, and also in one control brain, of a child who had suffered seizures [4]. Many of these excess disordered neurons proceed through apoptosis at a later stage, and this programmed cellular death appears to stimulate local gliosis/glial activation.

In a previous article on autism [6], we presented evidence supporting our theory that glyphosate may play a causal role in autism through its mimicry of the amino acid glycine. We analyzed data suggesting that glyphosate's mimicry would disrupt calcium inflow to immature neurons. For example, glyphosate may act at the glycine receptor of neurons (GlyR) which is a key to modulating the amount of chloride outflow from the immature neuron. This could cause inappropriate neuron membrane depolarizations, which then could force haphazard dislodgements of the magnesium ion from its blocking position within the N-methyl-D-aspartate (NMDA) receptor channel at the neuron membrane. This magnesium ion dislodgment could lead to excess and haphazard inflows of calcium into the immature neuron (if simultaneously the glycine binding site and glutamate binding site of the NMDA receptor are also agonistically bound). Glyphosate would plausibly induce excess bioavailability of glutamate by interfering with manganese-dependent conversion of glutamate to glutamine.

One signal that such excess calcium inflows are happening to neurons in autistic brains would be the finding of a reduction in the calcium buffering capacity remaining in neurons. Stoner et al., demonstrated just such a reduced calcium buffer content within poorly migrating autistic neurons [4]. The interested reader is referred to our previous paper for more details.

In [7], it was proposed that manganese chelation by glyphosate can explain a number of human pathologies that are currently on the rise, including autism. A study by Krüger et al., in 2013 showed that all the cows on 8 different Danish dairy farms that were fed genetically modified Roundup ${ }^{\oplus}$ Ready corn and soy feed had extremely low serum levels of manganese and cobalt [8]. The levels were well below the minimum of the typical range of values expected. In [7], it was discussed how low manganese bioavailability would lead to impaired mitochondrial function due to disabled manganese-dependent superoxide dismutase (Mn-SOD) as well as an impaired ability to detoxify glutamate by converting it to glutamine, using a manganese-dependent enzyme. Both mitochondrial impairment and glutamate toxicity are linked to autism. Here, we focus on the effects of manganese deficiency on the disruption of phosphatase activity, and the ramifications leading to low thyroid activity.

\section{Review}

Autism is a complex disorder of brain development characterized by repetitive behavior patterns and difficulties with social communication and interaction. It is believed to usually originate in utero, although there is also a form of regressive autism that occurs postnatally, which is not the subject of this paper. Maternal hypothyroidism is linked to autism in the fetus $[9, \mathbf{1 0}]$ and there is evidence from the neurological research literature supporting this link. We begin here with a review of selected features regarding the normal thyroidrelated physiology relevant to our theory. As is well-known, the in-utero fetus is heavily dependent upon the mother's production of thyroid hormone for neurodevelopment (see Figure 4). Maternal T4 (thyroxine) and T3 (triiodothyronine) cross the placenta and interact with cells in the fetus [11].

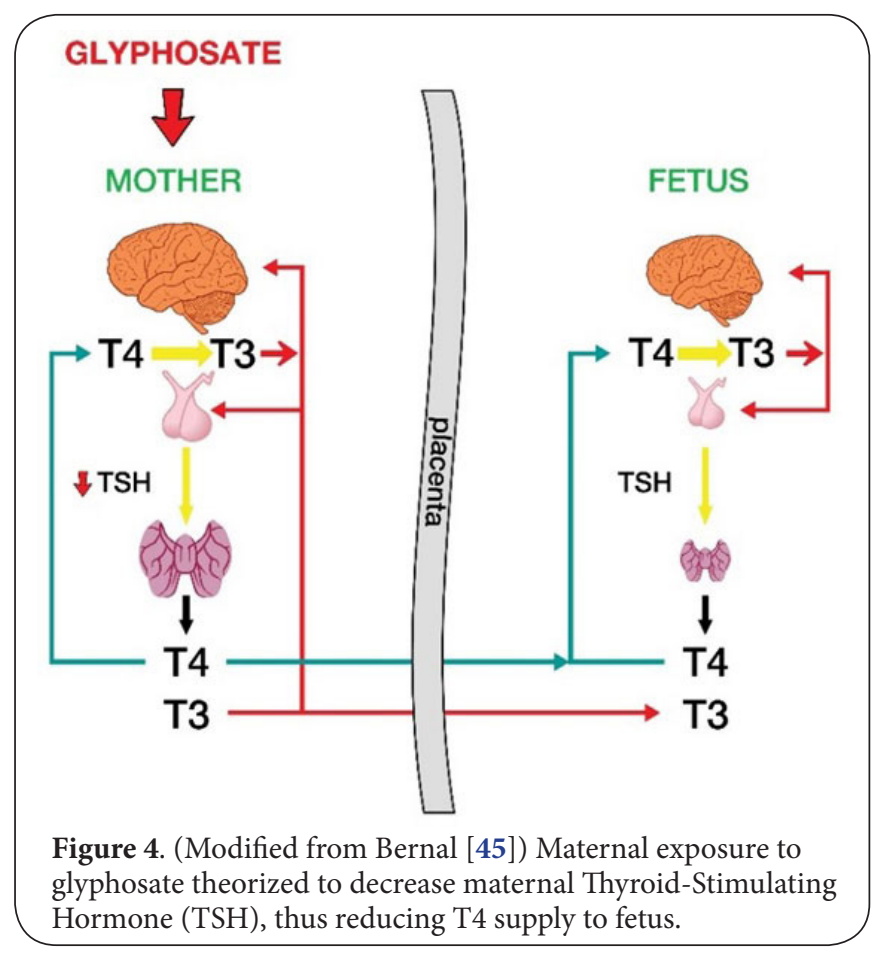

Fetus dependent on maternal thyroid hormone supply The active form of thyroid hormone, T3, is produced from T4 by the action of a deiodinase enzyme (D2), found for example within astrocytes (see Figure 5). D2 removes an iodine from a molecule of T4 to produce T3, the active molecule. So criti$\mathrm{cal}$ is the proper level of T3 to the developing neuron that another deiodinase, D3, acts within the neuron to reduce the T3 concentration, should it get too high. In the case of maternal hypothyroxinemia, a reduced supply of maternal T4 can be at least partially corrected by the astrocyte, such as by increasing its D2 activity [10]. Increased D2 activity in the fetal astrocyte will more avidly de-iodinate the available $\mathrm{T} 4$, so as to compensate for the reduced T4 supply from the mother. Another compensatory mechanism involves 


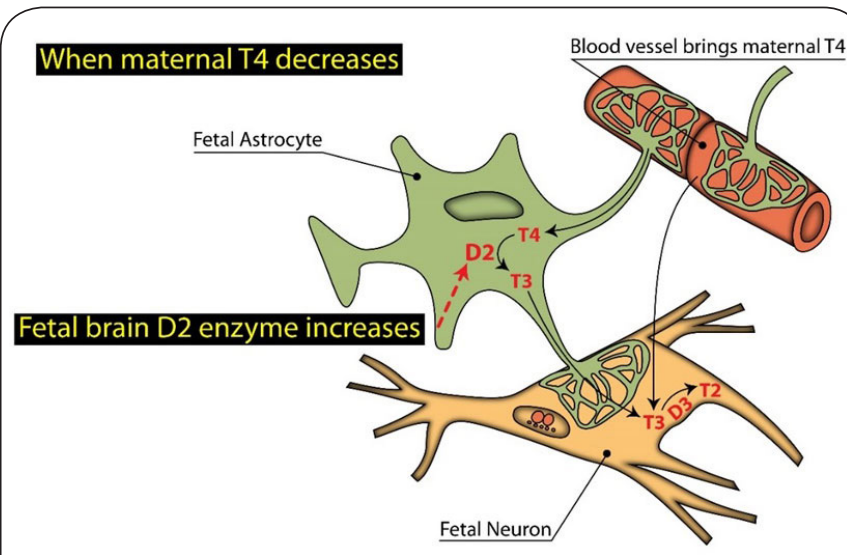

Figure 5. (Modifed from Bernal [45]) Activity of deiodinases within astrocytes and neurons.

increased expression of thyroid hormone receptor genes, as we discuss below.

Therefore, to evaluate whether glyphosate reduces T4 availability, we might look for increases in either D2 or beta thyroid hormone receptor mRNA, both of which may be induced within a fetus facing maternal hypothyroxinemia secondary to glyphosate dosing. In fact, glyphosate-formulated herbicide exposure alters gene expression for thyroid hormone receptor beta and deiodinase enzyme, with different alterations depending on stage/gender [12]. Specifically, in tadpoles, exposure to glyphosate-formulated herbicide is linked to an increase in expression of thyroid receptor beta in brain [13], presumably as a defense mechanism in the face of low T4. Furthermore, developmental delay was linked to glyphosate-formulated herbicide exposure in tadpoles [14].

\section{The pituitary/thyroid feedback control system}

The normal levels of TSH, T4 and T3 in the body are controlled within a feedback system, as shown in Figure 6. The hypothalamus detects decreased T4 and/or decreased T3 levels in the blood. In response to low levels, the hypothalamus produces and releases thyrotropin-releasing hormone (TRH). Passing through the hypophyseal portal channel to the pituitary, TRH binds with the TRH receptor of the thyrotrope in the anterior pituitary. The thyrotrope receptor for TRH is a G-protein coupled receptor which binds TRH (see Figure 7). Following binding of TRH, the receptor may then become displaced from the cell membrane, engulfed within a clathrin-coated vesicle and processed inside the thyrotrope (10).

In a clinical study of autistic boys, Hashimoto found a blunted TSH response to TRH stimulation [15]. We believe this can be predicted to be a consequence of manganese deficiency. Ordinarily, the process of TRH receptor binding of TRH causes the release of TSH from the pituitary. The alpha TSH subunit combines with the beta TSH subunit to form active TSH within the thyrotrope (Figure 9). However, in the case of glyphosate exposure, there would be interference with the re-cycling of

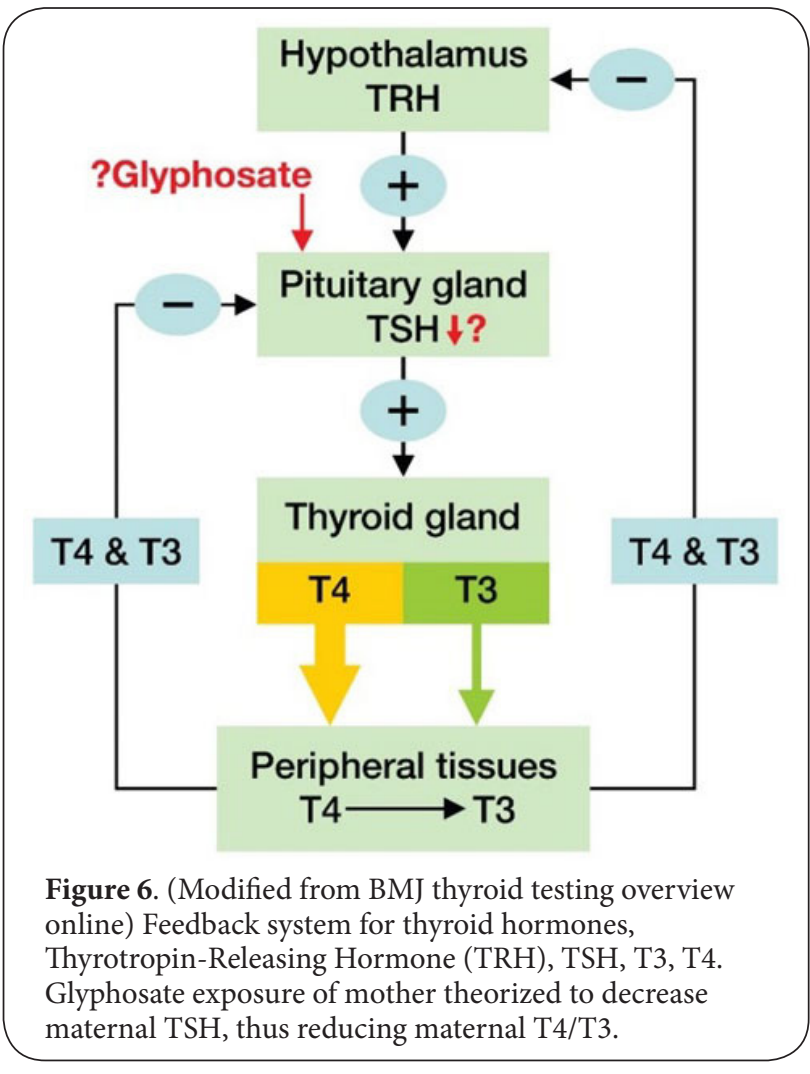

the TRH receptor, due to insufficient manganese to support protein phosphatase 1 (PP1) activity, leading to reduced release of TSH, as explained below.

\section{Metal chelation by glyphosate/GFH}

In 1978, Madsen et al., in their report on the chemical properties of glyphosate, noted its propensity to form stable chelates with metal cations [16]. From kinetics characterized in figure 2 in their paper, one can predict that, at the physiologic $\mathrm{pH}$ range of approximately 7.4 , in an idealized liquid medium with adequate glyphosate, up to half of the manganese cations could be bound in stable chelate with glyphosate, thus reducing their bio-availability. At lower pH levels even less manganese would be available.

Mervosh et al. [17], writing in the journal Weed Science in 1991, reported further on this well-known cation chelating capacity of glyphosate, indicating that it appears to occur intracellularly, i.e., within plant cells, due to action of adjuvants promoting penetration of glyphosate into the cell. They proposed that cation chelation is the main mechanism by which glyphosate exerts its lethal action in killing weeds. In the years that followed, scientists began to explore the possibility that glyphosate/GFH exposure in animals produced harmful effects in a similar manner, including by glyphosate chelating cations in food, thus reducing metal cation distribution/bioavailability, and/or by molecular action directly within the body, including within animal cells $[\mathbf{7 , 8 , 1 8 - 2 1 ]}$. 


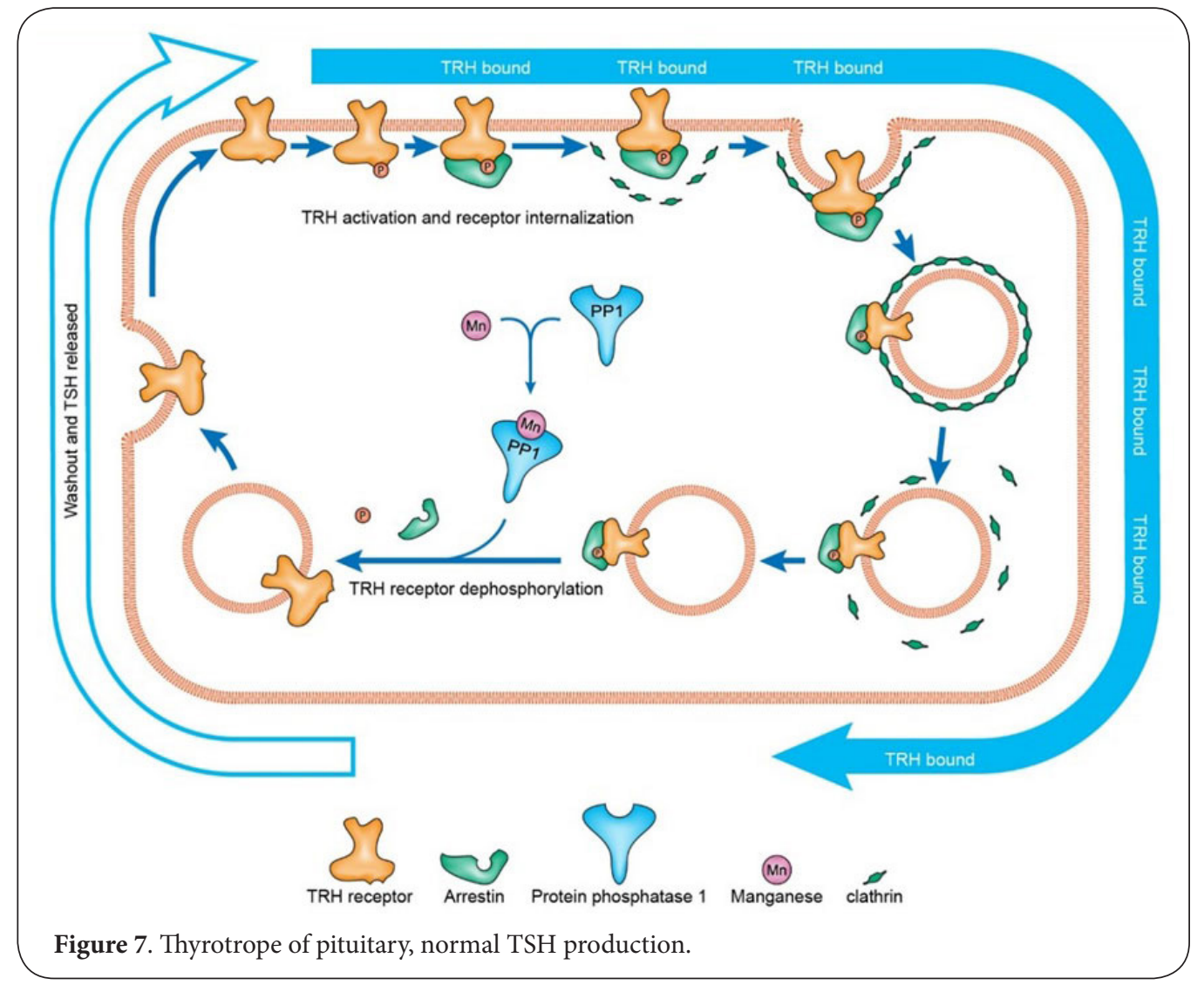

Studies have documented that glyphosate also chelates zinc $[16,22,23]$. Because zinc is required for the synthesis of thyroid hormones, it is possible that lack of bioavailable zinc is a contributory factor in hypothyroidism [24]. Supplementing zinc could conceivably lessen the chance of hypothyroidism. As supportive evidence, Tizhe et al., documented a protective effect of zinc supplementation in Wistar rats dosed with glyphosate [25].

\section{Details of the thyrotrope, TRH receptor function, PP1 enzyme}

As shown in Figure 7, the normal signal processing of TRH within the pituitary involves a recycling of the TRH receptor, from the membrane to the cell interior and back to the membrane, which depends upon the action of PP1.

The TRH receptor, after binding with TRH, is typically located within a vesicle inside the thyrotrope. PP1 removes the bound phosphate from the receptor, by dephosphorlyating the receptor/TRH combination. This permits the assembly and release of TSH from the pituitary [26]. Typically, the TRH receptor, after de-phosphorylation, is enabled to move back to re-join the cell membrane, where it can become available to bind another molecule of TRH.

Importantly, as demonstrated in studies by Gerhet and Hinkle $[\mathbf{2 7}, \mathbf{2 8}]$, manganese is a necessary co-factor for PP1's dephosphorylation of the receptor. Due to glyphosate's well-known ability to chelate divalent metal cations [22,23], we hypothesize that glyphosate gains entry within the thyrotrope and chelates ionic manganese, interfering with PP1 dephorphorylation (see Figure 8).

As schematically illustrated in Figure $\mathbf{8}$, where the co-factor manganese is chelated by glyphosate, and PP1 is thus unable to de-phosphorylate the receptor, the result is reduced TSH release. Multiple animal studies on glyphosate have provided evidence that pituitary cells in animals exposed to glyphosate exhibit increased protein content of beta TSH subunits (i.e., the beta subunits accumulate un-assembled) $[29,30]$.

\section{Impaired TSH production}

TSH formation typically occurs from the joining together of an inactive alpha TSH subunit and an inactive beta TSH subunit. When these are successfully joined (Figure 9), the TSH can be exported to the circulation in active form. The alpha TSH subunit is nearly identical to that of human chorionic gonadotropin (hCG), luteinizing hormone (LH) and folliclestimulating hormone (FSH). The TSH beta subunit confers the specificity to TSH.

GFH exposure causes the beta TSH subunits to accumulate unused within the thyrotrope cytoplasm. A study by Romano et al., presents findings of glyphosate dosing of pregnant rats which includes data of male offspring pituitaries having the predicted beta TSH subunit accumulation [29]. In addition, male 


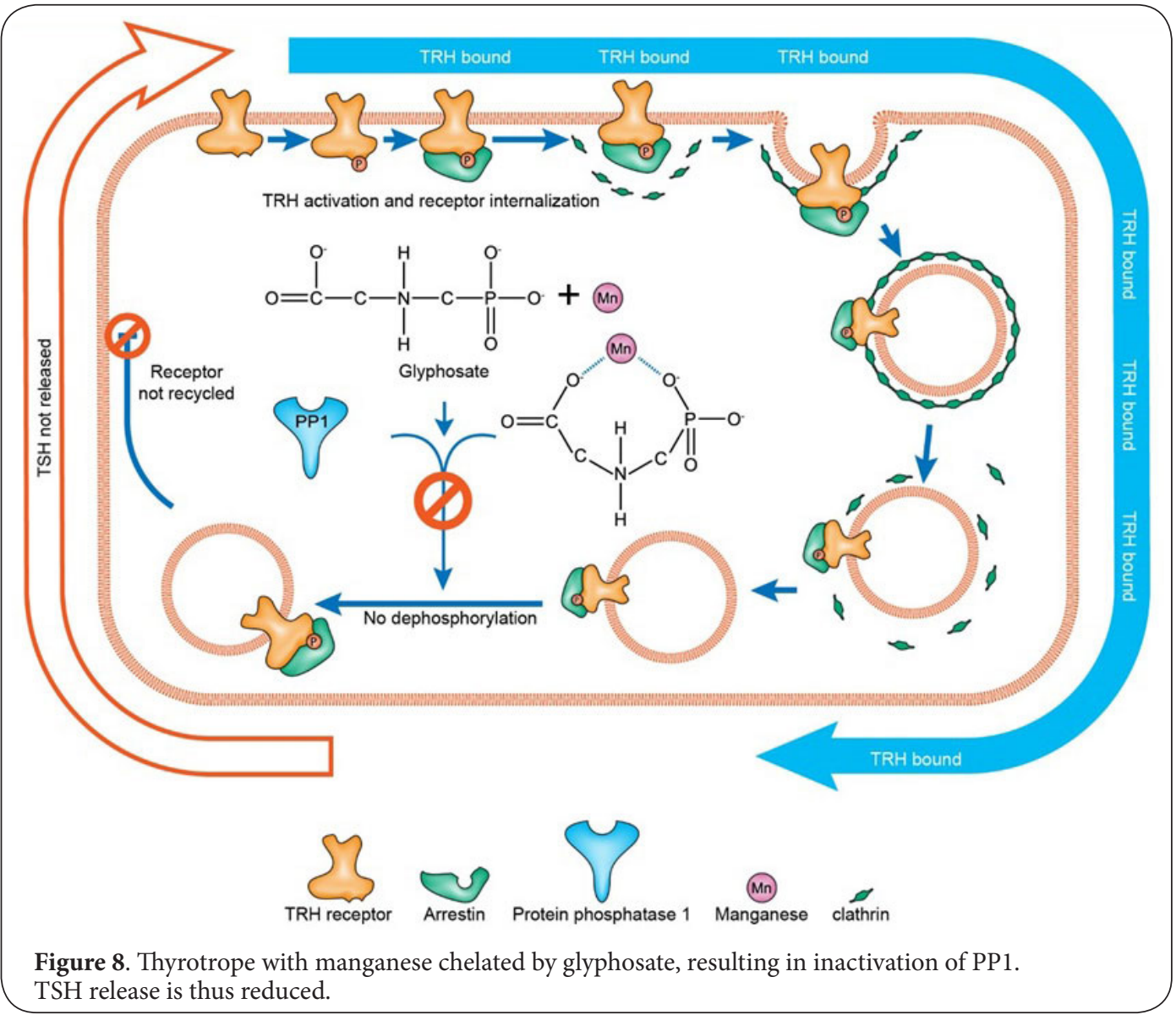

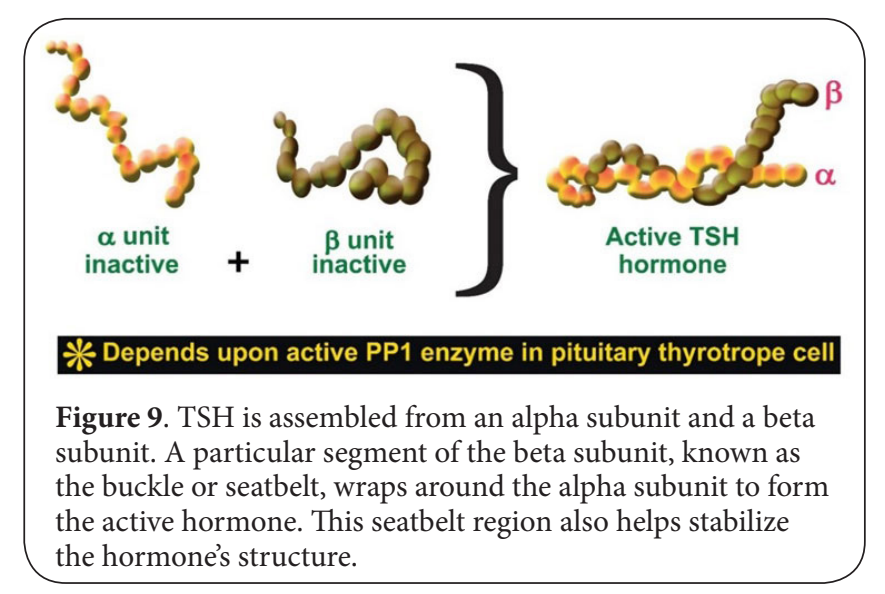

offsprings' pituitary content of beta TSH mRNA was reduced [30], presumably due to product inhibition of the unassembled beta subunit. The defect, we believe, is at the level of the PP1 enzyme, putatively due to lack of manganese co-factor.

Iodine deficiency versus protein phosphatase deficiency lodine deficiency is an important factor in hypothyroidism, and the effects are likely more acute in the context of impaired thyroid stimulation due to exposure to GFH. Lavado-Autric et al., studied the effect of iodine deficiency on fetal neuron migration [31]. They examined the brains of the offspring of pregnant rat dams fed an iodine deficient diet, and found autism-like neuron migratory defects in the fetal/neonate brains. Others have also linked iodine deficiency and autism. Hamza et al., studied 50 autistic Egyptian children and their mothers compared to 50 control pairs [32]. They found that iodine deficiency was prevalent in both the children and their mothers, with a statistically significant inverse relationship between iodine content and disease severity. They speculated that iodine deficiency could cause autism.

Glyphosate-induced hypothyroidism might produce signs and symptoms in an animal (or in a human) beyond those caused by iodine deficiency. For example, various symptoms and signs within various organs and systems may reflect GFH's manganese-chelation inactivation of PP1. PP1 influences glycogen's mobilization into glucose when muscle cells require glucose [33]. If such activity is reduced by glyphosate's chelating of manganese within the body, the animal's muscles may function poorly, producing muscle/activity-related signs. Slower weight gain might also be expected due to the poor mobilization of glycogen during animal growth. A study on glyphosate exposure to dogs found that the female dogs ex- 
posed to $926 \mathrm{mg} / \mathrm{kg}$ bw per day of glyphosate showed a gradual reduction in growth rate over time, compared to controls, which was consistently significant from week 23 onwards [34]. Okadaic acid is a toxin from shellfish which is known to inhibit protein phosphatases. Okadaic acid overdose often presents with diarrhea [35]. Diarrhea is much less likely to be seen in iodine deficiency-induced hypothyroidism. A study by Koch et al., found that phosphatase inhibitors okadaic acid and calyculin-A both inhibited corticotropin-releasing factor (CRF)-induced secretion of ACTH in AtT-20 corticotropes [36]. A regulatory study exposing rats to glyphosate found that soft stools and/or diarrhea occurred in both genders at all doses [37]. This could be an effect of inhibition of protein phosphatase, similar to that of okadaic acid overdose. Several manganese-dependent prokaryotic protein phosphatases with numerous biological roles have been identifed [38] and therefore decreased manganese bioavailability can be expected to disrupt the gut microbiome in unpredictable ways.

\section{Impaired selenoprotein function}

Gut commensals provide many essential nutrients to the body [39]. In particular, Lactobacillus participates in bacterial fixation of inorganic selenium into more bioavailable organic forms such as selenocysteine and selenomethionine. Lactobacillus critically depends on manganese for protection against oxidative damage $[\mathbf{4 0 , 4 1 ]}$. Lactobacillus reduction due to glyphosate's chelation of manganese [18] might therefore reflect reduced selenoprotein availability. lodothyroninedeiodinases, glutathione peroxidase and thioredoxin reductase are all selenoproteins, and these enzymes are involved in thyroid hormone metabolism, regulation of redox state and protection from oxidative damage [42].

\section{Fetal neuron migration due to maternal hypothyrox- inemia, litter size/weight}

As mentioned above, in a study of rat dams fed an iodine deficient diet [31], researchers sacrificed male offspring at 40 days postnatal and examined the brains. The fetal cortex of the sacrificed male rats displayed misplaced neurons and a blurring of the cortical layering.

The researchers also noted that feeding the rat dams an iodine-deficient diet had not reduced litter size or litter total weight, or offspring body weight, or offspring postnatal growth measures. Hence, we should acknowledge that neuron migration defects can occur in an animal without also finding disruption of litter size, litter weight, offspring body weights, or other changes to postnatal growth measures.

A key factor to consider is how short the maternal exposure to a factor disruptive of thyroid function can be to still induce neuron migration defects in offspring. In a study by Auso et al., researchers used rat dams and applied only a 3 day course of a goitrogen during the period of early fetal neurodevelopment [43]. The goitrogen was demonstrated to have depressed maternal thyroid hormones transiently to $70 \%$ of their normal level.

Importantly, the rat dams did not demonstrate clinical signs of hypothyroidism. Yet, when the male offspring were sacrificed at day 40 postnatal and their brains examined, $83 \%$ demonstrated significant alteration of neuronal arrangement in the cortex with numerous misplaced neurons. Furthermore, there were functional alterations in the behavior of the offspring rats. When the offspring were exposed at day 39 postnatal to acoustic stimuli, $53 \%$ of them responded with wild runs, which were followed in some offspring by seizures.

Reduced maternal serum TSH level in mid-pregnancy has been linked to increased risk of autism in human offspring $[9,10]$. While not easily observed or detected in animal studies, research has demonstrated that, in humans, maternal hypothyroxinemia during pregnancy appears linked to a reduction in the offspring child's IQ, as well as to impaired attention, language, and visual-motor performance at 7-9 years [44-46].

Altered thyroid hormone receptor expression in the brain Under normal circumstances, thyroid hormone receptors expressed in the fetal brain are predominantly of the alpha 1 type. $T 3$ binds to these fetal brain receptors in order to activate genes in the nucleus [47]. By contrast, thyroid hormone receptor beta (THR beta) usually has only low expression in the fetal period, and in normal circumstances demonstrates an increased expression only during the postnatal period and through adulthood. However, with pregnancy complicated by maternal hypothyroxinemia, compensatory mechanisms in the brain of the in utero fetus are likely to include an increase in the fetal brain's expression of thyroid hormone receptor beta $[45,48,49]$.

In tadpoles, glyphosate-formulated herbicides alter the expression of key genes involved in development, with changes in mRNA levels differently affected depending on developmental stage [13]. There was a clear dose-response effect for a glyphosate-formulated herbicide to increase thyroid hormone receptor beta expression in tadpole brain [13]. Tadpoles also have shown increased time to metamorphosis [14]. Delay in growth/development of earthworms was demonstrated with glyphosate exposure in environmentally relevant amounts [50].

\section{Myxedema coma and acute glyphosate poisoning}

Severe hypothyroidism can lead to myxedema coma, particularly among the elderly under conditions of stress such as acute infection [51]. It is associated with low body temperature, hypoventilation and respiratory acidosis, low blood pressure, hyponatremia, hypercapnia, hypoxia, and slowed and irregular heart rate. Many of these symptoms are characteristic features of acute glyphosate poisoning due to attempted suicide [52,53]. For example, hypercapnia, respiratory distress necessitating intubation, altered consciousness, low blood pressure, hypoxemia and shock are all listed as acute reactions to glyphosate poisoning. Hypercapnia leads 
Beecham et al. Journal of Autism 2016,

to respiratory acidosis, which is also a characteristic feature of acute glyphosate poisoning.

A case study of an elderly woman who was admitted to hospital in a state of coma is illustrative of the dramatic effect that can occur through induction of hypothyroidism through poisoning [54]. The woman had consumed an overabundance of uncooked bok choy, which possesses an enzyme capable of blocking thyroid function. Emergency treatment included thyroid hormone injections and she eventually recovered. However, untreated myxedema coma comes with a very high $50 \%$ mortality rate.

In reviewing data from animal studies of glyphosate/GFH dosing, we should be watching for similar thyroid-related collapse in animals. Death following glyphosate exposure may be a consequence of endocrine collapse. Hypothermia was noted in a regulatory study of rats exposed to glyphosate, along with subdued behavior with hunched posture and decreased activity 6 hours after dosing in 3 of 10 females at the highest dose [37]. This is suggestive of endocrine reduction/protein phosphatase inactivation symptoms. One female of the 3 was found dead on day 2 of the study. Researchers originally ascribed this death to general toxicity of glyphosate, but in view of the possibility of myxedema coma, deaths are suggestive of endocrine failure. Another female animal, from the lowest dose group, also died, again approximately 6 hours after dosing on day 1. The short half-life of TSH [55] may render glyphosate capable of inducing endocrine collapse in just a few hours.

\section{Inflammation and cytokines}

As suggested in a study by Hsiao et al., in circumstances where inflammation in the mother passes cytokines to the placenta/fetus, there might be a reduction in the overall total weight of a litter [56]. They found that cytokines can inhibit growth hormone activity. Furthermore, Wajner et al., noted that IL-6-induced oxidative stress reduces deiodinases D1 and D2, thus reducing conversion of T4 to T3, as well as increasing D3-mediated inactivation of T3 [57]. Dahlgren et al., found that IL- 6 passes the placental barrier [57]. Wei et al., noted that IL-6 is active in the brain $[\mathbf{5 9}, \mathbf{6 0}]$ and they theorized that IL- 6 causes adverse action in neurodevelopmental diseases, including mediating autismlike signs and symptoms. In a separate report, Wei et al., found elevated IL-6 in the cerebellum of autistic brains [60].

Glyphosate has been shown to induce an inflammatory response in both acutely-exposed humans and in in animal studies. Sato et al., reported the case of a 58 year old woman who had ingested approximately $150 \mathrm{ml}$ of a glyphosateformulated liquid ( $41 \%$ glyphosate and $15 \%$ polyoxethyleneamine) [62]. Two days later she was admitted to hospital in acute respiratory distress with circulatory collapse, renal failure, disseminated intravascular coagulopathy and aseptic meningitis. A sample of her cerebrospinal fluid was tested and demonstrated the presence of glyphosate $(122.5 \mathrm{mg} / \mathrm{ml})$ and a significant elevation of IL-6 $(394 \mathrm{mg} / \mathrm{ml})$. All signs and symptoms suggesting meningitis resolved as the concentration of glyphosate in CSF decreased. She was discharged after 39 days of hospitalization.

Mice exposed to glyphosate-rich air or glyphosate alone in air developed high eosinophil and neutrophil counts, mast cell degranulation, and production of IL-33, thymic stromal lymphopoietin (TSLP), and IL-13 [63]. TSLP induces IL-6 expression and is linked to asthma, chronic obstructive pulmonary disease, and atopic dermatitis [64]. IL-6 promotes a chronic inflammatory response by stimulating T-cells and B-cells [65]. This is significant because inflammation is known to be capable of damaging neurodevelopment $[66,67]$. Increased thymus weight in male mice during glyphosate exposure at intermediate and highest doses hints at harmful glyphosate action via inflammatory thymus hyperplasia, most prominent in males [34].

\section{Other manganese-dependent enzymes}

Numerous enzymes within the human body depend on manganese as a co-factor. Thus, removing bioactivity of manganese by chelation could allow a toxin to cause symptoms in several organ systems, simultaneously [7]. For example, manganese is essential for mitochondrial protection from oxidative damage, the production of energy from glucose, the growth of bones, the development of the skeleton and the formation of cartilage, among other key functions $[68,69]$. Therefore, in reviewing animal studies, we should watch for any signs related to these multiple functions.

While excess manganese in the body is known to be toxic, a deficiency of manganese has been found to produce maldevelopment and mal-functioning of nerves and muscles $[70,71]$. Multiple studies have linked autism to manganese deficiency. One study showed reduced manganese content in hair and/or urine as compared to controls [72], and another study showed reduced manganese levels in the enamel of deciduous teeth [73]. Mn-SOD is essential for protecting the mitochondria from oxidative damage, and it requires manganese as a co-factor. In a study of autistic children under 6 years of age, SOD activity (presumably including Mn-SOD activity) was found to be significantly reduced as compared with age-matched controls [74].

Estimates suggest that in nearly one-third of enzymemediated processes, metal ion co-factors are required for activity. For example, topoisomerase (TI) enzymes use divalent metal cations for their activity, principally magnesium and manganese [75]. Tl enzymes are key for proper gene expression, especially with regard to long kilobase genes. There are a number of different types of topoisomerases, each specializing in a different aspect of DNA manipulation such as unwinding/breaking-reattaching DNA strands (TP1) so that DNA can be copied/replicated, DNA supercoiling adjustments, and (TP2-gyrase) alternately condensing/de-condensing DNA.

King et al. [76] recently reported that many of the genes regulated by topoisomerases are involved in the function of 
synapses, the junctions between neurons, and many of these genes are also linked to autism. King et al., cross-referenced their list of genes regulated by topoisomerases with autism candidate genes catalogued by various sequencing studies and by SFARI Gene, a comprehensive database of genes linked to autism. They found that 49 of the 183 candidate autism genes were affected by topoisomerases -27 percent -a proportion much higher than would be seen by chance.

In our view, Tl enzyme inhibition via manganese chelation could explain the high incidence of discordant sibling mutations in autism cases, as found for example by Yuen et al., in whole genome sequencing of quartet families [77]. In other words, via the same manganese-chelation mechanism, one child in a family might suffer a disabling/mutation of one particular autism-related gene, while his/her sibling might suffer a disabling/mutation of a different autism-related gene. One possibility as to the level at which these disparate effects might occur would be at the level of paternal spermatozoa [78-80].

\section{Autism, hypothyroidism and mid-pregnancy TSH} Hypothyroidism in Western countries is often associated with Hashimoto's thyroiditis, an autoimmune condition. As mentioned above, in non-Western areas of the world, iodine deficiency is the predominant cause of hypothyroidism. With iodine deficiency, hypothyroid symptoms and low serum T4 are typically found in the face of elevated serum TSH. By contrast, we would expect glyphosate/GFH dosing in animals, via manganese chelation, to cause hypothyroidism with a reduced serum TSH level.

Such a reduction in serum TSH was found in a study of pregnant women in California with regard to autism spectrum disorder (ASD) risk in offspring. Yau et al. studied maternal mid-pregnancy serum samples and infant blood samples after birth in regard to three groups of children born in Orange County, CA in 2000-2001 including ASD $(n=78)$, developmental delay $(n=45)$, and general population controls (GP) ( $n=149)$ [10]. Adjusted logistic regression models showed inverse association between ASD and log transformed mid-pregnancy TSH levels in maternal serum samples (ASD vs. GP: OR [95\% Cl] $0.330 .12-0.91]$ ).

\section{PP2A and cancer}

Guyton et al., recently reported, in Lancet Oncology, the decision of the International Agency for Research on Cancer Monograph Working Group (IARC) to designate glyphosate as a 'probable carcinogen [81]. Ironically, two years earlier, a report appeared in that same journal [82] indicating that protein phosphatase 2A (PP2A) had been found genetically altered or functionally inactivated in many solid cancers and leukemia. It is known that PP2A requires manganese as co-factor [83].

While the animal dosing studies we will review do not focus on the issue of cancer, if glyphosate/GFH exposure in humans is capable of inactivating PP1, it is conceivable that
PP2A might be similarly inactivated by GFH exposure. The IARC report mentioned that PP2A, under ordinary circumstances, "maintains cell homeostasis by counteracting most of the kinase-driven intracellular signaling pathways." Indeed, the report called PP2A "a bona fide tumor suppressor."

\section{Discussion}

This paper has developed the hypothesis that glyphosate may be contributing to the autism epidemic in part through its suppression of thyroid hormone production. We have presented supporting evidence from a diverse literature, including epidemiological evidence from temporal correlations, regulatory and other animal toxicology studies, studies characterizing the symptoms of acute glyphosate poisoning, and the research literature relating autism in the offspring to maternal hypothyroidism.

In order to clarify explicitly whether autism-type changes can be caused in fetal brains due to maternal exposure to glyphosate/GFH from consumption of common food and beverages, relevant animal dosing studies need to be carefully designed. Such studies are increasingly important to fund and conduct because the incidence of autism is rising alarmingly. If exposure to glyphosate/GFH from common food and beverages is a factor in autism, governmental and medical authorities need such information, as do prospective parents, in particular pregnant women.

\section{Considerations for study design}

Autism in laboratory animals has a significant social interaction and behavioral component. Observers carrying out standard animal-testing protocols for regulatory chemical toxicity assessment are likely unaware of the appropriate signs of autistic behaviors, such as alterations in scent marking or vocalization distress. Furthermore, they are not specifically looking for autism-like behaviors in their assessment of toxicity effects. Autism is associated with changes originating at the early stages of fetal brain development. Therefore, the nature of toxic effects must be addressed in the context of the pregnant animal and in utero fetus, and carefully evaluated by appropriate protocol. This is not within the standard design typically used in chemical toxicity testing in animals for regulatory purposes.

One can gain statistical significance by considering the entire litter. In a 2013 study, Swiss researchers reviewed several earlier studies of autism using the valproic-acid-injected animal model [84]. They concluded that $91 \%$ (31 out of the 34 studies) suffered from statistical limitations, due to a failure to use the litter as a level of statistical analysis, rather than just analyzing the individual mouse or rat. This will be an important consideration in the design of future experiments on glyphosate.

In humans, the critical period during which fetal neurons migrate into the neocortex is approximately between the $12^{\text {th }}$ through $20^{\text {th }}$ weeks of gestation [85]. By comparison, the 
Beecham et al. Journal of Autism 2016,

critical period in rats tends to be from embryonic day E12 to E19 of gestation [86]. Thus, studies of GFH dosing in animals should include a carefully planned histologic examination of the brain according to a specific and detailed protocol designed to expose pregnant dams during the critical period and detect neuron migration defects in the offspring. Anything less will not be able to assess the types of changes within the cortical layering pattern of neurons which appear to be key to finding autism-type alterations. Also, gene expression and enzyme activities related to neurodevelopment should be assessed. The standard chemical toxicity testing protocols obviously do not include such evaluations. Nevertheless, we believe that there can be value in reinterpreting the data from earlier toxicology studies in light of new insight gained from knowledge of plausible mechanisms, provided we understand the limitations.

In regard to glyphosate/GFH, and based on our review of evidence from the scientific literature, a number of associated research areas also appear likely to yield meaningful information. Several of these are listed below, with a brief summary of evidence already found in various studies on glyphosate, along with relevant citations from the published scientific literature.

\section{Glyphosate/GFH and the disabling of pituitary protein phosphatase 1 (PP1)}

Perinatal exposure to glyphosate in rat dams decreased the content of beta subunit TSH mRNA in male rat offspring pituitary, while increasing pituitary beta subunit TSH protein content [29]. A related study in humans [10] showed that maternal TSH level mid-pregnancy was found to be inversely proportional to the risk of ASD in offspring. Other features in presented studies which suggest hypothyroidism from glyphosate exposure are subdued behavior [33], hypothermia [63], decreased physical activity [34,37], hunched posture [36] and decreased growth rates/body weights, especially in females [34].

\section{Glyphosate/GFH and endocrine collapse}

The symptoms of acute glyphosate poisoning include several that are specifically associated with myxedema coma due to excess stress under hypothyroidism [52,53]. Decreased survival of tadpoles from glyphosate-formulated exposure was apparently endocrine related [13]. In various rat studies, possible endocrine failure was suggested by several unexplained animal deaths following glyphosate dosing, especially in females [34].

Soft stools/diarrhea in rats and muscle/skeletal dysfunction, as suggested by hunched posture [34], suggest other aspects of PP1 inactivation. In tadpoles exposed to glyphosate formulations containing POEA, decreased snout-vent length at metamorphosis and increased time to metamorphosis, tail damage, and gonadal abnormalities were found [14].

\section{Glyphosate/GFH and toxic action by gender}

In tadpoles, glyphosate-formulated herbicide exposure re- duced the normal increase of mRNA for Thyroid Receptor beta during developmental Gosner stages Gs37-42 [12]. However, at Gs42, only males demonstrated this effect, suggesting that females are hormonally protected in utero. This is a possible explanation of male predominance in autism incidence.

\section{Conclusions}

Many different factors have been purported to be linked to autism. These have included, among others, genetic factors, iodine deficiency, vitamin D deficiency, and toxic exposures to a variety of substances, including lead, mercury, aluminum, thimerosal, fluoride, particulate matter in air pollution, to name a few. Whether, and to what magnitude, glyphosate/ GFH have a place on the list is still debatable.

This paper presents a hypothesis that glyphosate exposure in utero can cause developmental defects leading to autism due in part to impaired thyroid function in the mother and in the fetus. Hypothyroxinemia in rat dams fed an iodine-deficient diet (15) caused neuron migration defects in the brains of offspring reminescent of those observed in association with autism. If glyphosate causes even borderline hypothyroxinemia in mothers exposed to glyphosate-formulated herbicides, as studies we suggest be carried out might definitively establish, then we see no reason to believe such exposure could not produce, in human fetuses, similar disordered neuron migration. Glyphosate can be expected to impair thyroid function both through depletion of manganese essential for the production of TSH in the pituitary and through inhibition of the synthesis of multiple selenoproteins involved in thyroid function.

Compelling evidence comes from research by Yau et al., which showed that a decrease in mid-pregnancy maternal TSH correlates statistically with a higher risk of ASD in the offspring of such pregnancies [10]. Although only trace amounts of glyphosate/GFH are thought to be present in commonly consumed food and beverages, even such small exposures at critical times in development might cause autism-type neuron migration defects in the in-utero fetus. Glyphosate-resistant weeds growing among genetically engineered Roundup ${ }^{\circledast}$-Ready crops have necessitated ever increasing use of glyphosate on core crops of the processed food industry. Furthermore, the now widespread practice of desiccation, i.e., the spraying of crops with glyphosate just days before the harvest, on wheat, sugar cane, legumes, and other crops, has further raised residue levels in staple crops and therefore in many processed foods. These foods are not required to be labelled with the level of GFH residue present, and are almost never tested.

We have reviewed in a broader context evidence of thyroid dysfunction in association with glyphosate exposure, and have found support related to acute glyphosate poisoning and myxedema coma in humans, as well as impaired growth, lowered IQ, hypothermia, and decreased physical activity, all related to hypothyroidism.

We urgently encourage researchers with appropriate 
Beecham et al. Journal of Autism 2016,

resources to consider carrying out carefully designed studies, including glyphosate/GFH dosing to pregnant animals while using glyphosate-free feeding diets for control animals. Examination of offspring should include detecting signs of autistic behavior in animals. Also, careful histologic review of brain tissue should be carried out to specifically look for signs of fetal neuron migration defects and/or other features commonly found in autistic brains.

We acknowledge that we have not yet proven that glyphosate/GFH exposure from common food and beverages causes human autism. On the other hand, we have perhaps highlighted glyphosate's/GFH's molecular potential, through a set of deduced mechanisms. This theory will have served its purpose if it spurs appropriate future research, including as outlined above. If that research confirms our hypothesis, it will also have enabled strategies to effectively reduce the incidence of autism. Regardless, mothers are advised to consume and feed their family an organic diet as a precautionary measure.

\section{List of abbreviations}

ACTH: Adrenocorticotropic hormone CALB1: Calbindin 1

CRF: Corticotrophin-releasing factor

GFH: Glyphosate-formulated herbicide

GlyR: Glycine receptor of neurons

hCG: Human chorionic gonadotropin

IARC: International Agency for Research on Cancer

LH: Luteinizing hormone

MnSOD: Mitochondrial superoxide dismutas

NMDA: N-methyl- D-aspartate receptor

POEA: Polyethoxylatedtallowamine

PP1: Protein phosphatase 1

THR: Thyroid hormone receptor

TRH: Thyrotropin-releasing hormone

TSH: Thyroid- Stimulating Hormone

TSLP: Thymic stromal lymphopoietin

\section{Competing interests}

The authors declare that they have no competing interests.

Authors' contributions

\begin{tabular}{|l|c|c|}
\hline Authors' contributions & JEB & SS \\
\hline Research concept and design & $\checkmark$ & $\checkmark$ \\
\hline Collection and/or assembly of data & $\checkmark$ & $\checkmark$ \\
\hline Data analysis and interpretation & $\checkmark$ & $\checkmark$ \\
\hline Writing the article & $\checkmark$ & $\checkmark$ \\
\hline Critical revision of the article & $\checkmark$ & $\checkmark$ \\
\hline Final approval of article & $\checkmark$ & $\checkmark$ \\
\hline Statistical analysis & $\checkmark$ & $\checkmark$ \\
\hline
\end{tabular}

\section{Acknowledgement and funding}

This research is supported in part by Quanta Computers,

Taiwan, under the auspices of the Qmulus project.

Publication history

Editor: David Reiss, Imperial College London, UK.

Received: 06-Nov-2015 Final Revised: 09-Dec-2015

Accepted: 11-Jan-2016 Published: 18-Jan-2016

\section{References}

1. Swanson N L, Leu A, Abrahamson J and Wallet B. Genetically engineered crops, glyphosate and the deterioration of health in the United States of America. Journal of Organic Systems. 2014; 9.

2. Krüger $M$, Schledorn $P$, Schrödl H-W, Lutz W and Shehata AA. Detection of glyphosate residues in animals and humans. J Environ Anal Toxicol. $2014 ; 4: 2$.

3. Greig LC, Woodworth MB, Galazo MJ, Padmanabhan $\mathrm{H}$ and Macklis JD. Molecular logic of neocortical projection neuron specification, development and diversity. Nat Rev Neurosci. 2013; 14:755-69. | Article | PubMed Abstract | PubMed FullText

4. Stoner R, Chow ML, Boyle MP, Sunkin SM, Mouton PR, Roy S, WynshawBoris A, Colamarino SA, Lein ES and Courchesne E. Patches of disorganization in the neocortex of children with autism. N Engl J Med. 2014; 370:1209-19. | Article | PubMed Abstract | PubMed FullText

5. Lopez-Hurtado E and Prieto J J. A Microscopic Study of Language-Related Cortex in Autism Am. J Biochem Biotech. 2008; 4:130-45. I Pdf

6. Beecham J E and Seneff S. The possible link between Autism and Glyphosate Acting as Glycine Mimetic - a review of evidence from the literature with analysis. J Molec Genet Med. 2015; 9:4. I Article

7. Samsel A and Seneff S. Glyphosate, pathways to modern diseases III: Manganese, neurological diseases, and associated pathologies. Surg Neurol Int. 2015; 6:45. | Article | PubMed Abstract | PubMed FullText

8. Krüger M, Schrödl W, Neuhaus J and Shehata A A. Field Investigations of Glyphosate in Urine of Danish Dairy Cows. J Environ Anal Toxicol. 2013; 3:186. | Article

9. Roman GC, Ghassabian A, Bongers-Schokking JJ, Jaddoe VW, Hofman A, de Rijke YB, Verhulst FC and Tiemeier H. Association of gestational maternal hypothyroxinemia and increased autism risk. Ann Neurol. 2013; 74:733-42. | Article | PubMed

10. Yau VM, Lutsky M, Yoshida CK, Lasley B, Kharrazi M, Windham G, Gee N and Croen LA. Prenatal and neonatal thyroid stimulating hormone levels and autism spectrum disorders. J Autism Dev Disord. 2015; 45:719-30. | Article I PubMed

11. Sack J. Thyroid function in pregnancy - maternal-fetal relationship in health and disease. Pediatr Endocrinol Rev. 2003; 1 Suppl 2:170-6. | Article | PubMed

12. Lanct' ot C, Navarro-Martín L, Robertson C, Park B, Jackman P, Pauli B D and Trudeau V L. Effects of glyphosate-based herbicides on survival, development, growth and sex ratios of wood frog (Lithobates sylvaticus) tadpoles. II: agriculturally relevant exposures to Roundup ${ }^{\circledR}$ WeatherMax $^{\circledR}$ and VisionMax ${ }^{\circledR}$ under laboratory conditions. Aquat Toxicol. 2014; 154:291-303.

13. Navarro-Martin L, Lanctot C, Jackman P, Park BJ, Doe K, Pauli BD and Trudeau VL. Effects of glyphosate-based herbicides on survival, development, growth and sex ratios of wood frogs (Lithobates sylvaticus) tadpoles. I: chronic laboratory exposures to VisionMax(R). Aquat Toxicol. 2014; 154:278-90. | Article | PubMed

14. Howe CM, Berrill M, Pauli BD, Helbing CC, Werry K and Veldhoen N Toxicity of glyphosate-based pesticides to four North American frog species. Environ Toxicol Chem. 2004; 23:1928-38. | Article I PubMed

15. Hashimoto T, Aihara R, Tayama M, Miyazaki M, Shirakawa $Y$ and Kuroda $Y$. Reduced thyroid-stimulating hormone response to thyrotropin-releasing hormone in autistic boys. Dev Med Child Neurol. 1991; 33:313-9. | Article I PubMed

16. Madsen H E and Christensen H H. Gottleib Petersen C Stability Constants of Copper (II), Zinc, Manganese (II), Calcium and $\mathrm{M}$ agnesium Complexes of $\mathbf{N}$-(Phosphonomethyl) glycine (Glyphosate) Acta Chemica Scandanavica A. 1978; 32:79-83.

17. Mervosh T L and Balke N E. Effects of Calcium, Magnesium and Phosphate on Glyphosate Absorption by Cultured Plant Cells. Weed Science. 1991; 39:347-53. | Article

18. Samsel A and Seneff S. Glyphosate, pathways to modern diseases II: Celiac sprue and gluten intolerance. Interdiscip Toxicol. 2013; 6:159-84. | Article | PubMed Abstract | PubMed FullText 
Beecham et al. Journal of Autism 2016,

19. Krüger M, Schledorn P, SchrödI W, Hoppe HW and Lutz W et al. Detection of Glyphosate Residues in Animals and Humans. J Environ Anal Toxicol. 2014; 4:210

20. Séralini G, Clair E, Mesnage R and Gress S et al. Republished study: longterm toxicity of a Roundup herbicide and a Roundup-tolerant genetically modified maize. Environmental Sciences Europe. 2014; 26:14. I Pdf

21. Gasnier C, Dumont C, Benachour N, Clair E, Chagnon MC and Seralini GE. Glyphosate-based herbicides are toxic and endocrine disruptors in human cell lines. Toxicology. 2009; 262:184-91. | Article | PubMed

22. Jayasumana C, Gunatilake S and Senanayake P. Glyphosate, hard water and nephrotoxic metals: are they the culprits behind the epidemic of chronic kidney disease of unknown etiology in Sri Lanka? Int J Environ Res Public Health. 2014; 11:2125-47. | Article | PubMed Abstract | PubMed FullText

23. Caetano M S, Ramalho T C, Botrel D F, da Cunha E F and de Mello W C. Understanding the Inactivation Process of Organophosphorus Herbicides: A DFT Study of Glyphosate Metallic Complexes with Zn2, Ca2, Mg2, Cu2, Co3, Fe3, Cr3, and Al3. International Journal of Quantum Chemistry. 2012; 112:27522762. | Article

24. Betsy A, Binitha M and Sarita S. Zinc deficiency associated with hypothyroidism: an overlooked cause of severe alopecia. Int J Trichology. 2013; 5:40-2. | Article | PubMed Abstract | PubMed FullText

25. Tizhe EV, Ibrahim ND, Fatihu MY, Onyebuchi, II, George BD, Ambali SF and Shallangwa JM. Influence of zinc supplementation on histopathological changes in the stomach, liver, kidney, brain, pancreas and spleen during subchronic exposure of Wistar rats to glyphosate. Comp Clin Path. 2014 23:1535-1543. | Article | PubMed Abstract | PubMed FullText

26. Jiang X, Dias, J A and He X. Structural biology of glycoprotein hormones and their receptors: Insights to signaling. Molecular and Cellular Endocrinology. 2014; 382:424451. | Article

27. Gehret A U and Hinkle P M. Protein Phosphatase 1alpha is involved in the regulation of the thyrotropin-releasing hormone receptor. FASEB J. 2012; 26:Ib180. | Article

28. Hinkle PM, Gehret AU and Jones BW. Desensitization, trafficking, and resensitization of the pituitary thyrotropin-releasing hormone receptor. Front Neurosci. 2012; 6:180. | Article | PubMed Abstract | PubMed FullText

29. R. Romano, P. Souza, M. Nunes and M. Romano. Perinatal exposure to a commercial formulation of glyphosate reduces the mRNA expression and increases the protein content of beta TSH in the pituitary of male offspring. Endocrine Abstracts. 2012; 29:753. | Article

30. Romano R, Souza P, Nunes M and Romano M. Perinatal exposure to a commercial formulation of glyphosate reduces the mRNA expression and increases the protein content of beta TSH in the pituitary of male offspring. Endocrine Abstracts. 2012; 29:P753.

31. Lavado-Autric R, Auso E, Garcia-Velasco JV, Arufe Mdel C, Escobar del Rey F, Berbel P and Morreale de Escobar G. Early maternal hypothyroxinemia alters histogenesis and cerebral cortex cytoarchitecture of the progeny. J Clin Invest. 2003; 111:1073-82. I Article I PubMed Abstract PubMed FullText

32. Hamza RT, Hewedi DH and Sallam MT. Iodine deficiency in Egyptian autistic children and their mothers: relation to disease severity. Arch Med Res. 2013; 44:555-61. | Article I PubMed

33. Brady MJ and Saltiel AR. The role of protein phosphatase-1 in insulin action. Recent Prog Horm Res. 2001; 56:157-73. | Pdf | PubMed

34. World Health Organization and Food and Agriculture Organization of the United Nations. Pesticide residues in food - 2004. Report of the Joint Meeting of the FAO Panel of Experts on Pesticide Residues in Food and the Environment and the WHO Core Assessment Group on Pesticide Residues Rome, Italy, 2029 September 2004.

35. Yasumoto T, Murata M, Oshima Y, Sano M and Matsumoto G K et al. Diarrhetic shellfish toxins. Tetrahedron. 1985; 41:1019-25.

36. Koch B and Lutz-Bucher B. Inhibition of protein phosphatases by okadaic acid and calyculin-A differentially modulates hormonal- and forskolinstimulated formation of cyclic AMP in AtT-20 corticotrophs: effect of pituitary adenylate activating polypeptide and corticotropin-releasing factor. Cell Signal. 1994; 6:467-73. | Article | PubMed
37. Pfeil R, Niemann and L. Glyphosate. Federal Institute for Risk Assessment, Berlin, Germany. JMPR. 2004; 95-169.

38. Shi L. Manganese-dependent protein O-phosphatases in prokaryotes and their biological functions. Front Biosci. 2004; 9:1382-97. | PubMed

39. Morowitz MJ, Carlisle EM and Alverdy JC. Contributions of intestinal bacteria to nutrition and metabolism in the critically ill. Surg Clin North Am. 2011; 91:771-85. | Article | PubMed Abstract | PubMed FullText

40. Nierop Groot MN and de Bont JA. Involvement of manganese in conversion of phenylalanine to benzaldehyde by lactic acid bacteria. Appl Environ Microbiol. 1999; 65:5590-3. | Article | PubMed Abstract | PubMed FullText

41. Archibald FS and Duong MN. Manganese acquisition by Lactobacillus plantarum. J Bacteriol. 1984; 158:1-8. | Article | PubMed Abstract | PubMed FullText

42. Schomburg L. Selenium, selenoproteins and the thyroid gland: interactions in health and disease. Nat Rev Endocrinol. 2012; 8:160-71. | Article I PubMed

43. Auso E, Lavado-Autric R, Cuevas E, Del Rey FE, Morreale De Escobar G and Berbel P. A moderate and transient deficiency of maternal thyroid function at the beginning of fetal neocorticogenesis alters neuronal migration. Endocrinology. 2004; 145:4037-47. | Article | PubMed

44. Zimmermann MB, Aeberli I, Melse-Boonstra A, Grimci L, Bridson J, Chaouki $\mathrm{N}, \mathrm{Mbhenyane} \mathrm{X}$ and Jooste $\mathrm{PL}$. lodine treatment in children with subclinical hypothyroidism due to chronic iodine deficiency decreases thyrotropin and C-peptide concentrations and improves the lipid profile. Thyroid. 2009; 19:1099-104. | Article | PubMed

45. Bernal J. Thyroid hormone receptors in brain development and function. Nat Clin Pract Endocrinol Metab. 2007; 3:249-59. | Article | PubMed

46. Qian M, Wang D, Watkins WE, Gebski V, Yan YQ, Li M and Chen ZP. The effects of iodine on intelligence in children: a meta-analysis of studies conducted in China. Asia Pac J Clin Nutr. 2005; 14:32-42. | Pdf | PubMed

47. Yamamoto N, Li QL, Mita S, Morisawa S and Inoue A. Inhibition of thyroid hormone binding to the nuclear receptor by mobilization of free fatty acids. Horm Metab Res. 2001; 33:131-7. | Article | PubMed

48. Patel J, Landers K, Li H, Mortimer RH and Richard K. Thyroid hormones and fetal neurological development. J Endocrinol. 2011; 209:1-8. Article | PubMed

49. Dong H, You SH, Williams A, Wade MG, Yauk CL and Thomas Zoeller R. Transient Maternal Hypothyroxinemia Potentiates the Transcriptional Response to Exogenous Thyroid Hormone in the Fetal Cerebral Cortex Before the Onset of Fetal Thyroid Function: A Messenger and MicroRNA Profiling Study. Cereb Cortex. 2015; 25:1735-45. I Article I PubMed

50. Santadino M, Coviella C and Moma F. Glyphosate Sublethal Effects on the Population Dynamics of the Earthworm Eisenia Fetida (Savigny 1826). Water Air Soil Pollution. 2014; 225:2207. | Article

51. Wall CR. Myxedema coma: diagnosis and treatment. Am Fam Physician. 2000; 62:2485-90. | Article | PubMed

52. Lee $\mathrm{HL}$, Chen KW, Chi CH, Huang JJ and Tsai LM. Clinical presentations and prognostic factors of a glyphosate-surfactant herbicide intoxication: a review of 131 cases. Acad Emerg Med. 2000; 7:906-10. | Article | PubMed

53. Talbot AR, Shiaw MH, Huang JS, Yang SF, Goo TS, Wang SH, Chen CL and Sanford TR. Acute poisoning with a glyphosate-surfactant herbicide ('Roundup'): a review of 93 cases. Hum Exp Toxicol. 1991; 10:1-8. | Article I PubMed

54. Chu $\mathrm{M}$ and Seltzer TF. Myxedema coma induced by ingestion of raw bok choy. N Engl J Med. 2010; 362:1945-6. | Article | PubMed

55. Szkudlinski MW, Fremont V, Ronin C and Weintraub BD. Thyroid-stimulating hormone and thyroid-stimulating hormone receptor structure-function relationships. Physiol Rev. 2002; 82:473-502. | Article | PubMed

56. Hsiao EY and Patterson PH. Activation of the maternal immune system induces endocrine changes in the placenta via IL-6. Brain Behav Immun. 2011; 25:604-15. | Article | PubMed Abstract | PubMed FullText

57. Wajner SM, Goemann IM, Bueno AL, Larsen PR and Maia AL. IL-6 promotes nonthyroidal illness syndrome by blocking thyroxine activation 
Beecham et al. Journal of Autism 2016,

while promoting thyroid hormone inactivation in human cells. J Clin Invest. 2011; 121:1834-45. | Article | PubMed Abstract | PubMed FullText

58. Dahlgren J, Samuelsson AM, Jansson T and Holmang A. Interleukin-6 in the maternal circulation reaches the rat fetus in mid-gestation. Pediatr Res. 2006; 60:147-51. | Article | PubMed

59. Wei H, Chadman KK, McCloskey DP, Sheikh AM, Malik M, Brown WT and Li X. Brain IL-6 elevation causes neuronal circuitry imbalances and mediates autism-like behaviors. Biochim Biophys Acta. 2012; 1822:831-42. | Article | PubMed

60. Wei H, Alberts I and Li X. Brain IL-6 and autism. Neuroscience. 2013; 252:320-5. | Article | PubMed

61. Wei H, Zou H, Sheikh AM, Malik M, Dobkin C, Brown WT and Li X. IL-6 is increased in the cerebellum of autistic brain and alters neural cell adhesion, migration and synaptic formation. J Neuroinflammation. 2011; 8:52. | Article | PubMed Abstract | PubMed FullText

62. Sato $C$, Kamijo $Y$, Yoshimura $\mathrm{K}$ and Ide T. Aseptic meningitis in association with glyphosate-surfactant herbicide poisoning. Clin Toxicol (Phila). 2011; 49:118-20. | Article | PubMed

63. Kumar S, Khodoun M, Kettleson EM, McKnight C, Reponen T, Grinshpun SA and Adhikari A. Glyphosate-rich air samples induce IL-33, TSLP and generate IL-13 dependent airway inflammation. Toxicology. 2014; 325:42-51. | Article | PubMed Abstract | PubMed FullText

64. Shan L, Redhu NS, Saleh A, Halayko AJ, Chakir J and Gounni AS. Thymic stromal lymphopoietin receptor-mediated IL- 6 and CC/CXC chemokines expression in human airway smooth muscle cells: role of MAPKs (ERK1/2, p38, and JNK) and STAT3 pathways. J Immunol. 2010; 184:7134-43. | Article | PubMed

65. Gabay C. Interleukin-6 and chronic inflammation. Arthritis Res Ther. 2006; 8 Suppl 2:S3. | Article | PubMed Abstract | PubMed FullText

66. Miller BJ, Culpepper N, Rapaport MH and Buckley P. Prenatal inflammation and neurodevelopment in schizophrenia: a review of human studies. Prog Neuropsychopharmacol Biol Psychiatry. 2013; 42:92-100. Article | PubMed

67. Le Belle JE, Sperry J, Ngo A, Ghochani Y, Laks DR, Lopez-Aranda M, Silva $\mathrm{AJ}$ and Kornblum HI. Maternal inflammation contributes to brain overgrowth and autism-associated behaviors through altered redox signaling in stem and progenitor cells. Stem Cell Reports. 2014; 3:725-34. | Article | PubMed Abstract | PubMed FullText

68. Baly DL, Keen CL and Hurley LS. Pyruvate carboxylase and phosphoenolpyruvate carboxykinase activity in developing rats: effect of manganese deficiency. J Nutr. 1985; 115:872-9. | Article | PubMed

69. Armstrong CG, Browne GJ, Cohen P and Cohen PT. PPP1R6, a novel member of the family of glycogen-targetting subunits of protein phosphatase 1. FEBS Lett. 1997; 418:210-4. | Article | PubMed

70. Claus Henn B, Ettinger AS, Schwartz J, Tellez-Rojo MM, Lamadrid-Figueroa H, Hernandez-Avila M, Schnaas L, Amarasiriwardena C, Bellinger DC, Hu $\mathrm{H}$ and Wright RO. Early postnatal blood manganese levels and children's neurodevelopment. Epidemiology. 2010; 21:433-9. | Article | PubMed Abstract | PubMed FullText

71. Zota AR, Ettinger AS, Bouchard M, Amarasiriwardena CJ, Schwartz J, Hu $\mathrm{H}$ and Wright RO. Maternal blood manganese levels and infant birth weight. Epidemiology. 2009; 20:367-73. | Article | PubMed Abstract | PubMed FullText

72. Akyuzlu D K, Kayaalti Z, Soylemez E and Soylemezoglu T. Association between Autism and Arsenic, Lead, Cadmium, Manganese Levels in Hair and Urine. $J$ of Pharmacy and Pharmacol. 2014; 2:140-44.

73. Abdullah MM, Ly AR, Goldberg WA, Clarke-Stewart KA, Dudgeon JV, Mull CG, Chan TJ, Kent EE, Mason AZ and Ericson JE. Heavy metal in children's tooth enamel: related to autism and disruptive behaviors? J Autism Dev Disord. 2012; 42:929-36. | Article | PubMed

74. Meguid NA, Dardir AA, Abdel-Raouf ER and Hashish A. Evaluation of oxidative stress in autism: defective antioxidant enzymes and increased lipid peroxidation. Biol Trace Elem Res. 2011; 143:58-65. | Article | PubMed

75. Sissi $\mathrm{C}$ and Palumbo M. Effects of magnesium and related divalent metal ions in topoisomerase structure and function. Nucleic Acids Res. 2009; 37:702-11. | Article | PubMed Abstract | PubMed FullText
76. King IF, Yandava CN, Mabb AM, Hsiao JS, Huang HS, Pearson BL, Calabrese JM, Starmer J, Parker JS, Magnuson T, Chamberlain SJ, Philpot $\mathrm{BD}$ and Zylka MJ. Topoisomerases facilitate transcription of long genes linked to autism. Nature. 2013; 501:58-62. | Article | PubMed Abstract | PubMed FullText

77. Yuen RK, Thiruvahindrapuram B, Merico $D$, Walker $S$, Tammimies $K$, Hoang N, Chrysler C, Nalpathamkalam T, Pellecchia G, Liu Y, Gazzellone MJ, D'Abate L, Deneault $E$ and Howe JL et al. Whole-genome sequencing of quartet families with autism spectrum disorder. Nat Med. 2015; 21:18591. | Article | PubMed

78. Kong A, Frigge ML, Masson G, Besenbacher S, Sulem P, Magnusson G, Gudjonsson SA, Sigurdsson A, Jonasdottir A, Wong WS, Sigurdsson G, Walters GB, Steinberg S, Helgason H, Thorleifsson G, Gudbjartsson DF, Helgason A, Magnusson OT, Thorsteinsdottir U and Stefansson K. Rate of de novo mutations and the importance of father's age to disease risk. Nature. 2012; 488:471-5. | Article | PubMed Abstract | PubMed FullText

79. Degrassi F, Fiore M and Palitti F. Chromosomal aberrations and genomic instability induced by topoisomerase-targeted antitumour drugs. Curr Med Chem Anticancer Agents. 2004; 4:317-25. | Article | PubMed

80. Tamburrino L, Marchiani S, Montoya M, Elia Marino F, Natali I, Cambi M, Forti G, Baldi E and Muratori M. Mechanisms and clinical correlates of sperm DNA damage. Asian J Androl. 2012; 14:24-31. | Article | PubMed Abstract | PubMed FullText

81. Guyton KZ, Loomis D, Grosse Y, El Ghissassi F, Benbrahim-Tallaa L, Guha $\mathrm{N}$, Scoccianti C, Mattock H and Straif K. Carcinogenicity of tetrachlorvinphos, parathion, malathion, diazinon, and glyphosate. Lancet Oncol. 2015; 16:490-1. | Article | PubMed

82. Perrotti $D$ and Neviani P. Protein phosphatase 2A: a target for anticancer therapy. Lancet Oncol. 2013; 14:e229-38. | Article | PubMed Abstract | PubMed FullText

83. Xing $Y, X u Y, C$ Chen $Y$, Jeffrey PD, Chao $Y$, Lin Z, Li Z, Strack S, Stock JB and Shi Y. Structure of protein phosphatase 2A core enzyme bound to tumor-inducing toxins. Cell. 2006; 127:341-53. | Article | PubMed

84. Lazic SE and Essioux L. Improving basic and translational science by accounting for litter-to-litter variation in animal models. BMC Neurosci. 2013; 14:37. | Article | PubMed Abstract | PubMed FullText

85. Rabinowicz T, de Courten-Myers GM, Petetot JM, Xi G and de los Reyes E. Human cortex development: estimates of neuronal numbers indicate major loss late during gestation. J Neuropathol Exp Neurol. 1996; 55:320-8. | Article | PubMed

86. Ignacio MP, Kimm EJ, Kageyama GH, Yu J and Robertson RT. Postnatal migration of neurons and formation of laminae in rat cerebral cortex. Anat Embryol (Berl). 1995; 191:89-100. | Article | PubMed

\section{Citation:}

Beecham JE and Seneff S. Is there a link between autism and glyphosate-formulated herbicides? J Autism. 2016; 3:1.

http://dx.doi.org/10.7243/2054-992X-3-1 